\title{
Wkład Profesor Alodii Kaweckiej-Gryczowej w rozwój nauki o książce
}

Pani Profesor Gryczowa nie opublikowała żadnej rozprawy poświęconej w całości sformułowaniu własnego modelu badań księgoznawczych czy metodyce tych badań. Nie było to jednak spowodowane lekceważeniem, niedostrzeganiem potrzeby formułowania podstaw teoretycznych i zasad metodycznych dla tej dyscypliny. Wprost przeciwnie, niemal od początku swej pracy badawczej (i bibliotekarskiej) kierowała się przyszła Pani Profesor dobrze przemyślanymi zasadami, starała się też poznawać i pogłębiać znajomość założeń teoretycznych i metodycznych, śledząc pilnie literaturę fachową i naukową. Świadectwem tego są choćby Jej recenzje, zwłaszcza we wczesnym okresie, w latach trzydziestych XX wieku1. Wtedy były to głównie prace inkunabulistyczne. Świadomego przyjęcia pewnych dyrektyw, a przede wszystkim konsekwentnego ich przestrzegania wymagała też od innych, ostro nawet krytykując i wtedy i później, zwłaszcza w latach siedemdziesiątych $\mathrm{XX}$ wieku, autorów, którzy nieudolnie, a przede wszystkim niekonsekwentnie realizowali przyjęte przez siebie metody badań bądź stosowali je wybiórczo.

Sama metody badawcze i podstawy teoretyczne sformułowane przez Kazimierza Piekarskiego nie tylko przyjęła niemal w początkach swojej pracy, ale je propagowała przez całe właściwie życie. Niektóre sformułowania swego mistrza zresztą nieco modyfikowała, używając i proponując

1 A. M. Wolińska, Bibliografia prac prof. dr Alodii Kaweckiej-Gryczowej za lata 1926-1990, [w:] Z badań nad dawna ksiażka. Studia ofiarowane profesor Alodii KaweckiejGryczowej w 85-lecie urodzin, t. I, Warszawa 1991, s. 11-12, poz. 7, 8, 9, 13, 14, 15, 20, 23, 26. Niepełna bibliografia podmiotowa i przedmiotowa jest przy Jej biogramach, zob. Wspótcześni polscy pisarze i badacze literatury, t. IV, Warszawa 1996 (oprac. J. Czachowska), s. 87-91; Stownik badaczy literatury polskiej, red. J. Starnawski, t. 5, Warszawa 2002, s. 152-155, oprac. H. Tadeusiewicz. 
użycie innego, bardziej odpowiedniego słowa ${ }^{2}$ bądź kładąc nacisk na trochę inne niż Piekarski priorytety, licząc się także ze zdaniem innych specjalistów ${ }^{3}$ i ich propozycjami, ale przede wszystkim dbając o jak największą zrozumiałość. Przynajmniej kilkakrotnie, (jeżeli nie kilkanaście razy) w sposób przystępny, jasny przedstawiała, upowszechniała poglądy Piekarskiego. Przede wszystkim jednak generalnie przyjmując model skonstruowany przez niego, sama nie ustawała w poszukiwaniu coraz lepszych rozwiązań, zwłaszcza w wymiarze praktycznym - bardziej jasnego, a zarazem zwięzłego przedstawiania zaobserwowanych i zbadanych faktów. Wprowadzała nawet pewne graficzne rozwiązania, znaki ułatwiające zrozumienie, a przede wszystkim dające oszczędność miejsca przy opisach bibliograficznych. Przykładem jedna z późniejszych Jej prac, z 1974 r., bibliografia druków oficyn ariańskich Rodeckiego i Sternackiego, opublikowana zresztą w wersji dwujęzycznej, po polsku i po francusku ${ }^{4}$. Do tej niesłychanie ważnej publikacji naturalnie jeszcze powrócę.

Własne przemyślenia teoretyczne i metodyczne Profesor Gryczowej ujawniały się przede wszystkim w wynikach Jej badań prowadzonych zawsze wzorowo i konsekwentnie. Ujawniały się też w wielu Jej inicjatywach badawczych, organizowaniu prac zespołowych. Ale przedstawiała je także - niezbyt często zresztą - we fragmentach własnych książek i artykułów oraz we wstępach do redagowanych przez siebie tomów prac innych autorów, zwłaszcza z serii „Książka w Dawnej Kulturze Polskiej”,

${ }^{2}$ Np. przypominając, że według Piekarskiego badania nad dawną książką „dotyczą głównie trzech zespołów zagadnień: produkcji, rozpowszechniania i wreszcie konsumpcji”, objaśniła to ostatnie słowo: „tj. szerzenia się i rodzajów czytelnictwa” - zob. A. Kawecka-Gryczowa, Badania nad dawna książka w Bibliotece Narodowej, „Rocznik Biblioteki Narodowej”, 14:1978 (druk: 1980), s. 32, poz. 32 w bibliografii Wolińskiej.

${ }^{3}$ W rozprawie: Dzieje drukarstwa w Polsce XV $i$ XVI wieku. Stan badań i postulaty, [w:] Dawna książka i kultura. Materiaty międzynarodowej sesji naukowej z okazji pięćsetlecia sztuki drukarskiej w Polsce, pod red. S. Grzeszczuka i A. Kaweckiej-Gryczowej, Wrocław 1975, s. 9, poz. 150 wskazała, że Jan Muszkowski zmienił nieco terminologię Piekarskiego, zastępując pośrednictwo w rozpowszechnianiu książki obiegiem, a konsumpcję - użytkowaniem książki.

${ }^{4}$ Ariańskie oficyny wydawnicze Rodeckiego i Sternackiego. Dzieje i bibliografia, Wrocław-Genève 1974 (poz. 138). W opisach zastosowano 13 różnych znaków, wskazujących m.in. na występowanie w danym druku np. drzeworytu lub dedykacji, a także obramienia karty tytułowej.

${ }^{5}$ Tomem I tej serii były Studia nad ksią̇ka poświęcone pamięci Kazimierza Piekarskiego, Wrocław 1951, z obszernym tekstem Gryczowej: Dzieło Kazimierza Piekarskiego, (poz. 37), s. 39-61. Wcześniej jednak, w 1949 r., w serii tej ukazały się - jako tom II - Studia z zakresu bibliografii i ksiegoznawstwa Kazimierza Budzyka. W latach 1948-1983 w serii tej opublikowano 18 dzieł, w tym są Drukarze dawnej Polski od XV do XVIII wieku (5 tomów) i Dramat staropolski od początków do powstania sceny narodowej. Bibliografia (t. 1-2, t. II w 2 częściach). 
zainicjowanej przez Nią wraz z profesorem Kazimierzem Budzykiem, wywodzącym się zresztą także ze „szkoły” Kazimierza Piekarskiego.

Dążąc do konsekwentnego przestrzegania zasad, reguł, za najważniejsze jednak uznawała to, by były one zgodne $\mathrm{z}$ celem, jakiemu mają służyć. Bardzo wyraźnie pisała o tym np. w uwagach krytycznych do uzupełnień Bibliografii polskiej Estreichera ${ }^{6}$ (notabene sama ogłosiła taki wykaz w początkach swej pracy bibliotekarskiej) ${ }^{7}$. Dopuszczała pewną elastyczność, jeżeli były ku temu powody. Odwołam się tu do krótkiego słowa wstępnego Pani Profesor do mojej bibliografii druków emblematycznych z 1981 r., włączonej - jako tom XVIII do serii wspomnianej serii redagowanej przez Panią Profesor. W bibliografii tej odeszłam, zrezygnowałam z rozbudowanego szczegółowego opisu bibliograficznego stosowanego w tej serii. Ale Pani Profesor w słowie Od Redakcji stwierdziła: „Wyznajemy wszak zasadę, że metodę księgoznawczo-bibliograficzną powinna cechować elastyczność, innymi słowy taki dobór narzędzi roboczych, który jest podporządkowany naczelnej problematyce i uzależniony zarówno od celu pracy, jak i rodzaju tworzywa”. W mojej bibliografii, jak dalej napisała Profesor Gryczowa, „podstawowym kryterium doboru nie są jedynie teksty, lecz głównie materiał graficzny, względnie jego substytuty"8. Możliwość pewnej elastyczności, jednak tylko w uzasadnionych przypadkach i zawsze przy konsekwentnym stosowaniu zmodyfikowanych ewentualnie w jakimś punkcie założeń, dopuszczała Profesor Gryczowa i przy innych okazjach.

O pewnym modyfikowaniu, a może przede wszystkim rozszerzaniu i pogłębianiu przyjętych założeń badawczych, zawsze na podstawie rozważnych i ostrożnych przemyśleń teoretycznych i metodycznych, można przekonać się przeglądając uważnie kolejne prace samej Pani Profesor. Pewnej zmianie podlegał też język, zawsze jednak jasny i zrozumiały, w odróżnieniu np. od prac Kazimierza Budzyka, cenionego przez Nią wysoko, piszącego jednak dość zawile i czasem niezbyt jasno ${ }^{9}$. W przypad-

${ }^{6}$ Nad uzupetnieniami Bibliografii polskiej Estreichera, [w:] Z problemów bibliografii, „Prace Instytutu Bibliograficznego", nr 16, Warszawa 1970, (poz. 116); tu zwłaszcza s. 214-215.

${ }^{7}$ Bibliographica XVII w., „Pamiętnik Biblioteki Kórnickiej”, 2:1930, s. 103-116, (poz. 3). Jest to spis 32 druków nieznanych Estreicherowi bądź opisanych niedokładnie, bez znajomości egzemplarzy. Opis uzależniony jest właśnie od tego - jedynie rzeczywiście nieznane otrzymały pełny opis.

${ }^{8}$ Od Redakcji, [w:] P. Buchwald-Pelcowa, Emblematy $w$ drukach polskich i Polski dotyczacych XVI-XVIII wieku. Bibliografia, Wrocław 1981 (Książka w dawnej kulturze polskiej”, 18), s. [5].

${ }^{9}$ Gryczowa ceniła go zwłaszcza jako „uczonego zdolnego do ujęć teoretycznych, do porządkowania i uogólniania zjawisk", jak napisała po Jego śmierci w artykule pt. Kazimierz Budzyk bibliograf i księgoznawca, Przegl. Bibliot., 33:1965, z. 1, s. 26 (poz. 97). 
ku prac opublikowanych przez Profesor Gryczową, jestem przekonana, że nawet osoba bez specjalistycznego przygotowania fachowego może bez trudności z nich korzystać. Natomiast korzystanie z wielu prac księgoznawczych innych autorów, w znacznej mierze wskutek posługiwania się niewłaściwym słownictwem, mylenia określeń, może okazać się bardzo trudne. Wiąże się to zresztą z jednym $\mathrm{z}$ wielu wysuwanych przez Profesor Gryczową postulatów - uporządkowania terminologii, przygotowania rzeczywiście fachowego, zadawalającego badaczy słownika ${ }^{10}$.

O licznych postulatach, rozsianych w różnych pracach Profesor Gryczowej, też nie możemy zapominać, myśląc o Jej wkładzie w rozwój nauki o książce - bliższe Jej było określenie tej dziedziny wiedzy jako księgoznawstwo. Przez formułowanie postulatów wskazywała Gryczowa niejednokrotnie propozycje rozszerzania czy pogłębiania pewnych badań, perspektywy na przyszłość.

Na marginesie uwag o słownictwie fachowym chciałabym przypomnieć, jak żywo negatywnie reagowała na różne dziwne sformułowania i słówka, w tym na szerzące się obecnie właściwie powszechnie „starodruki” zamiast stare druki...

A właśnie stare druki, a raczej: dawna książka były głównym, choć nie jedynym przedmiotem Jej zainteresowań i badań. O poświęceniu się przede wszystkim starym drukom świadczy cała jej droga życiowa, zarówno lata pracy zawodowej, właśnie z nimi związane - od niezbyt długich w Bibliotece Kórnickiej (od 1 XI 1928 do 30 IX 1930) po długie lata w Bibliotece Narodowej, od 1 X 1930 formalnie do 30 IX 1974, tj. do przejścia na emeryturę, z dwiema przerwami. Pierwsza, spowodowana okupacją, trwała od lutego 1940 do 1 III 1944, gdyż na kilka miesięcy przed wybuchem powstania Gryczowa znów podjęła pracę jako „wolontariuszka". Była to jednak właściwie tylko formalnie przerwa, gdyż przez cały wspomniany okres pracowała, współpracując z Piekarskim, nawet i wtedy, gdy i On został przez Niemców zwolniony i jako chory posłany na emeryturę. Gryczowa kopiowała wtedy przede wszystkim bezcenne materiały rejestracyjne Piekarskiego, głównie inkunabulistyczne. Przechowywała je zresztą we własnym mieszkaniu, podczas gdy cały dorobek Piekarskiego został spalony wraz z ogromną masą najcenniejszych starych druków, inkunabułów, poloników, przeniesionych do Biblioteki Krasińskich. Dzięki tej pracy Gryczowej możliwe było po wojnie ponow-

${ }^{10}$ Postulowała to m.in. w zamieszczonej w „Zapiskach Historycznych” (43:1978, z. 3, s. 163) recenzji książki Z. Nowaka, Początki sztuki drukarskiej na Pomorzu w XV wieku, s. 163 (poz. 163). 
ne podjęcie prac nad centralnym katalogiem inkunabułów (z wykazem strat), a te prace nad inkunabułami to jedno z najważniejszych osiągnięć Pani Profesor i Jej wkładu do polskiej nauki o książce.

Drugą przerwą w formalnym związku z Biblioteką Narodową, a konkretnie z Działem (później nazywanym Zakładem) Starych Druków było kierowanie do 1 V 1945 aż do końca 1949 roku Oddziałem (później nazywanym Ośrodkiem) Dawnej Książki w Ministerstwie Oświaty. Ośrodek przeniesiono w 1950 r. do Biblioteki Narodowej, wtedy gdy i Gryczowa formalnie do niej powróciła. Czas powstania i miesiące po jego upadku poświęciła Gryczowa na ratowanie zbiorów (uczestniczyła w tzw. akcji pruszkowskiej). Emerytura też tylko formalnie zerwała jej związki z warsztatem Zakładu Starych Druków. Dopóki pozwalały Jej siły, niemal do ostatnich miesięcy pracowała tam przy swoim biurku, często, bardzo często, w niektórych okresach codziennie. Właśnie w tych latach po przejściu na emeryturę opublikowała tak wiele swych własnych prac, poświęconych starym drukom, dawnej książce, z Biblioteka ostatniego Jagiellona ... z 1988 r. na czele ${ }^{11}$. Natomiast rok przejścia w stan „spoczynku” zawodowego, 1974, upamiętniła podstawowym opracowaniem drukarń ariańskich ${ }^{12}$ i dorobku Macieja Wirzbięty ${ }^{13}$, a w roku następnym, w 1975 wydała zbiór swych wcześniejszych rozpraw ${ }^{14}$. Z okresu „emeryckiego” warto wymienić choćby nową, zmienioną także co do koncepcji wersję zwięzłej syntezy dziejów polskiej książki w XVI wieku (w rzeczywistości - także książki w Polsce tego okresu, z tym, że uwagę poświęciła książce drukowanej). Nie było to już Drukarstwo polskie $w$ dobie Odrodzenia (jak w pracy z 1953, poz. 42 i 1954 roku, poz. 46) czy Rola drukarstwa polskiego $w$ dobie Odrodzenia (jak w publikacjach z 1954, poz. 45 i 1956 r., poz. 50 oraz w zbiorze z 1975 r., poz. 149), ale

${ }^{11}$ Biblioteka ostatniego Jagiellona. Pomnik kultury renesansowej, Wrocław 1988 (poz. 182). Książka ta miała ze wszystkich prac Gryczowej najwięcej recenzji - ich wykaz w obszernym omówieniu tego dzieła dokonanym przez Janusza Tondela, „Rocznik Biblioteki Narodowej”, 30-31:1994-1995 (druk 1997), s. 322-323.

12 Zob. wyżej, przypis 4.

${ }^{13}$ W 1974 r. jako zeszyt 9 wydawnictwa „Polonia typographica saeculi sedecimi” ukazał się pierwszy z trzech poświęconych Wirzbięcie (poz. 140); następny, 10 (poz. 148) wydany został w 1975 r., a ostatni, 11 (poz. 171) - w roku 1981. Gryczowa zmieniła wtedy podtytuł serii, który pierwotnie brzmiał: „Zbiór podobizn zasobu drukarskiego tłoczni polskich XVI stulecia” na: „Tłocznie polskie XVI stulecia. M o n o g r a f i e” (wyróżnienie moje, P. B.-P.) i podobizny zasobów drukarskich. Zeszyty poświęcone Wirzbięcie, a zwłaszcza 11, dają rzeczywiście monograficzne opracowanie jego działalności, wnoszą też wiele do wiedzy o dziejach książki w drugiej połowie XVI i początkach XVII wieku.

${ }^{14}$ Z dziejów polskiej książki w okresie Renesansu. Studia i materiały, Wrocław 1975 (poz. 149). 
Miejsce ksiązki w kulturze polskiej XVI wieku ${ }^{15}$. W latach od 1975 do 1989 włącznie opublikowała też Gryczowa kilka zabytków literatury staropolskiej ${ }^{16}$, w tym niesłychanie interesujący tekst pt. Bogowie fatszywi, odszukany zresztą nie przez Nią samą, ale odnaleziony w Rumunii przez Elmera Lakò i Jej użyczony, opublikowany zresztą dwukrotnie, w 1981 i 1983 r. (poz. 173 i 179), gdyż pierwsza edycja z 1981 r. zawierała błędy. Utwór ten wpisywał się jak najbardziej w trwające od czasów studiów pod kierunkiem profesora Stanisława Kota Jej zainteresowania reformacją w Polsce, poświadczone tylu pracami, od najwcześniejszych poczynając, podsumowane jakby opublikowaniem w roku śmierci, tj. 1990, artykułu, którego współautorem był profesor Janusz Tazbir ${ }^{17}$. Natomiast na rok przed śmiercią, w 1989 r., ukazały się Jana Zaremby Pieśni Chwat Boskich, (poz. 199), wydrukowane w 1558 r. w Brześciu Litewskim przez Stanisława Murmeliusa. Było to swoiste dopełnienie pierwszej w ogóle publikacji z 1926 r., pt. Kancjonały protestanckie na Litwie w XVI w., (poz. 1), ogłoszonej w „Reformacji w Polsce”, w którym to czasopiśmie, a zwłaszcza jego kontynuacji pt. „Odrodzenie i Reformacja w Polsce”, ukazały się liczne Jej rozprawy, a także wspomniana już edycja utworu pt. Bogowie fatszywi. Bo zagadnienia związane z reformacją, a ściślej z książką związaną z ruchem reformacyjnym, były w dorobku naukowym Profesor Gryczowej szczególnie ważne.

Ukazywały się nadal redagowane i wydawane przez Gryczową prace zbiorowe, m.in. tomy Drukarzy dawnej Polski ${ }^{18}$. Nie ujrzała jednak przygotowywanego przez tyle lat, w czasach, gdy kierowała Zakładem Starych Druków i Ośrodkiem Opieki nad Dawną Książką, i potem, na emeryturze, tomu II centralnego katalogu inkunabułów w Polsce, zawierają-

${ }^{15}$ Miejsce książki w kulturze polskiej XVI wieku, [w:] Polska w epoce Odrodzenia. Państwo - Spoteczeństwo - Kultura, wyd. 2, Warszawa 1986, s. 411-454 (poz. 181). W pierwszej edycji tej pracy zbiorowej, również pod redakcją A. Wyczańskiego, nie było żadnej rozprawy poświęconej książce.

${ }^{16}$ Nieznane zabytki piśmiennictwa staropolskiego publikowała też wcześniej. Bardzo interesująca jest praca pt. Wokót Kongresu wiedeńskiego (1515). Nieznany utwór Pawta z Krosna, „Pamiętnik Literacki”, 42:1951 (druk 1952), s. 885-907 (poz. 38), przynosząca obok oryginału łacińskiego tłumaczenie na język polski, a w osobnej odbitce - także podobizny odszukanego w Bibliotece w Gdańsku druku.

${ }^{17}$ Le livre et la Réforme en Pologne (współautor: Janusz Tazbir), [w:] La Réforme et le livre. L'Europe de l'imprimé (1517 - v. 1570), Paris 1990, s. 417-440 (poz. 200).

18 Jako ostatnia za życia Gryczowej ukazała się w 1983 r. szczególnie chyba dla Niej ważna cz. 1 tomu 1: Matopolska. Wiek XV-XVI (poz. 178). Natomiast wcześniej, w 1977 r., opublikowano również cz. 1 tomu 3 poświęconą Wielkopolsce (poz. 157). Część 2 tomu 1: Małopolska. Wiek XVII-XVIII, w dwóch woluminach, ukazała się dopiero w 2000 roku pod redakcją J. Pirożyńskiego, a część 2 t. 3: Mazowsze z Podlasiem, pod red. K. Korotajowej i J. Krauze-Karpińskiej, w 2001 r. 
cego przede wszystkim straty wojenne. Notabene z opublikowaniem tego centralnego katalogu inkunabułów, a raczej z przeciągającymi się pracami nad nim, wiąże się chyba jedyna taka pomyłka Profesor Gryczowej, jeśli chodzi o planowanie, przewidywanie ukończenia pracy. Otóż $\mathrm{w}$ interesującym z wielu względów artykule pt. Kłopoty $z$ inkunabułami w skali międzynarodowej i polskiej (poz. 68), ogłoszonym w 1961 r. w „Przeglądzie Bibliotecznym”, artykule, w którym zapoznawała w sposób przystępny, a zarazem kompetentny, z problematyką z nimi związaną, informowała o pracach nad nimi, wyraziła nadzieję, że maszynopis centralnego katalogu inkunabułów powstanie do końca 1963 r., a jego publikacja „zdąży” na koniec pięciolatki. Jak wiemy, tom I w dwóch woluminach (poz. 120) ukazal się w r. 1970, a tom II (poz. 201) - w 1994 r. (na karcie tytułowej jest rok 1993) ${ }^{19}$. Ale wyraźnie trzeba powiedzieć, że prace te, a przede wszystkim ujawnienie strat wojennych stało się możliwe także dzięki temu, że Profesor Gryczowa dopomogła szczęśliwie przetrwać, ocaleć rejestracji przedwojennej Piekarskiego, przede wszystkim przez skopiowanie tych zeszytów, a potem przechowanie we własnym mieszkaniu. Notabene słowo „szczęście”, „szczęśliwy traf”, „szczęśliwie" często pojawia się w pracach Profesor Gryczowej: coś ocalało, coś się odnalazło, coś trafiło do Jej rąk. Jakby zapominała o tym, że tylko Jej wytężona praca, doskonała znajomość dawnej kultury pozwalała dostrzegać i wykorzystać te szczęśliwe trafy. Potwierdzić to może choćby edycja Tragedii ruskiej. Jedynie Jej fenomenalna pamięć i umiejętności pozwoliły uzupełnić zdefektowany tekst. Odnaleziony przez siebie druk w zbiorach z dawnej biblioteki w Podolińcu, przechowywany w Bratysławie, zdołała dopełnić jedną kartą, odnalezioną kilka lat wcześniej w Budapeszcie w oprawie druku rakowskiego. Dzięki temu edycja w 1973 r. (poz. 136), mogła zostać uzupełniona.

Nie sposób wymienić wszystkich dokonań Profesor Gryczowej choćby z tych ostatnich lat, które były tak owocne. Ale naturalnie ta „złota jesień” przynosząca tak wiele ważnych dzieł, nie była przypadkiem, ale zwieńczeniem całego długiego życia poświęconego pracy nad polską książką, zwłaszcza dawną, badaniom ważnego bardzo wycinka, a raczej elementu dziejów polskiej kultury. Jedną z wczesnych prac powojennych

${ }^{19}$ Incunabula quae in bibliothecis Poloniae asservantur, moderante A. Kawecka-Gryczowa, composuerunt M. Bohonos, E. Szandorowska, (t. 1, cz. 1-2), Vratislaviae 1970 (poz. 120); t. II, Addenda, indices, composuerunt M. Bohonos, M. Spandowski, E. Szandorowska, Vratislaviae 1993 (druk: 1994, poz. 201). Zwrócić należy uwagę na to, ile do wiedzy o książce XV wieku na ziemiach polskich wnoszą wstępy Profesor Gryczowej do obu tomów. 
pt. Fragmenta z 1952 r. (poz. 39), powstałą, tak jak wiele Jej prac, na marginesie niejako zajęć bibliotecznych, rejestracyjno-bibliograficznych, rozpoczęła od słów: „Dawna książka jest dokumentem przeszłości historycznej" ${ }^{20}$ wskazując na znaczenie badań nad nią dla różnych dyscyplin. Sama siebie określała jako historyka drukarstwa, ale była przede wszystkim historykiem kultury, specjalizującym się w dziejach książki polskiej, zwłaszcza dawnej. Nie zapomniała jednak nigdy o powiązaniu jej i z innymi dziedzinami życia w Polsce, polityką, ekonomią, ale też o związkach z książką europejską, europejskimi prądami umysłowymi i ideami. W słowie Od Redakcji w tomie Dawna ksiażka i kultura przynoszącym Materiały międzynarodowej sesji naukowej z okazji pięćsetlecia sztuki drukarskiej w Polsce pod Jej i Stanisława Grzeszczuka redakcją (Wrocław 1975) (poz. 152), czytamy przecież: Dzieje książki to ,jeden z istotniejszych elementów historii kultury"21. Ważne jest też dalsze stwierdzenie zawarte w tym słowie wstępnym - o tym, że sesja z 1974 r. (w której Profesor Gryczowa uczestniczyła tylko w części, ze złamaną nogą w gipsie) była próbą przeglądu stanu badań tych problemów, które składają się na historię dawnej książki, zarówno jej formy, jak też jej funkcji.

Dawnej książce poświęciła Profesor Gryczowa najwięcej swego trudu i Jej wkład w dokonania polskiej bibliologii to przede wszystkim prace poświęcone historii polskiej książki drukowanej, zwłaszcza z okresu wczesnego, z wieku XV i XVI, w mniejszym zaś zakresie z wieków późniejszych, choć przecież drukarstwu aż do końca XVIII wieku poświęcone są tomy Drukarzy dawnej Polski. Obszerne osobne opracowania pewnych ośrodków wydawniczych obejmowały też nie tylko wiek XVI, ale i XVII (Zamość - poz. 67 i przedruk z aneksem w poz. 149, Leszno - poz. 90 i również w poz. 149, Raków - poz. 62 i 38 oraz w pewnym stopniu poz. 198). Badała i opracowywała nie tylko książkę drukowaną na ziemiach państwa polskiego, ale i książkę obecną, użytkowaną, czytaną na tym terenie. Tym zagadnieniem zajmowała się nie tylko przy pracach przy centralnym katalogu inkunabułów czy wydaniu katalogów inkunabułów lub poloników XVI wieku z kilku bibliotek (Biblioteki Horynieckiej XX. Ponińskich przekazanej BN, poz. 19 z 1936 r., współautor K. Piekarski, Biblioteki Publicznej m.st. Warszawy, w 1949 r. inkunabuły, a w 1957 polonica XVI wieku, przy współautorstwie J. Adamczyk,

\footnotetext{
${ }^{20}$ Fragmenta, „Pamiętnik Literacki”, 43:1952, z. 3/4, s. 970 (poz. 39).

${ }^{21}$ Dawna ksiazka i kultura. Materiaty międzynarodowej sesji naukowej z okazji pięćsetlecia sztuki drukarskiej w Polsce, pod red. S. Grzeszczuka i A. Kaweckiej-Gryczowej, Wrocław 1975, s. (5), (poz. 152).
} 
poz. 55, inkunabułów Biblioteki Zakładu im. Ossolińskich we Wrocławiu - na podstawie materiałów K. Piekarskiego, poz. 49 z 1956 r. - dodać należy jeszcze inwentarz inkunabułów bibliotek cieszyńskich, o których piszę dalej) i w monografii biblioteki Zygmunta Augusta, ale badała też księgozbiór mało znanej postaci, kanonika sandomierskiego Macieja Becha, (akcentując przy tej okazji postulat prowadzenia badań proweniencyjnych ${ }^{22}$. Ważne ustalenia zawierają Jej przedwojenne prace o zbiorach historycznych Biblioteki Narodowej. W pierwszej wersji tekst zatytułowany Biblioteka Narodowa $w$ Warszawie był wstępem do Katalogu wystawy zbiorów historycznych Biblioteki Narodowej w Warszawie, wydanym w 1933 r. (poz. 5), potem - w postaci rozszerzonej - doczekał się drugiego wydania w 1934 r. (poz. 38). W omówieniach dorobku naukowego Profesor Gryczowej praca ta potraktowana jest raczej zdawkowo. W rzeczywistości to drugie wydanie, w postaci osobnej książ$\mathrm{ki}$, jest do dzisiaj bardzo cenne, wręcz niezastąpione jako źródło do dziejów narodowej książnicy, a zwłaszcza księgozbiorów Załuskich. Praca ta jest naturalnie stale wykorzystywana, cytowana, ale trochę zapomina się o tym, że ta mała książeczka zajmuje wcale nie małe miejsce w dorobku naukowym Gryczowej i stanowi znaczący wkład w naszą wiedzę i naukę o książce.

Profesor Gryczowa wniosła też ważny wkład do innych dziedzin nauki o książce, choć swoje myśli i przemyślenia przekazała czasem w pracach raczej skromnych, niewielkich. Myślę tu zwłaszcza o referacie wygłoszonym przez Nią na IV Zjeździe Bibliotekarzy Polskich w Warszawie w 1936 r. w Sekcji Księgoznawczej pt. Bibliotekarstwo publiczne, (poz. 16). Niewielki ten tekst - w odbitce z księgi Zjazdu to zaledwie 8 stron - docenił Krzysztof Migoń, stwierdzając, że Gryczowa w referacie tym „problematykę badań nad historią bibliotek w nowoczesny sposób" sformułowała właśnie ze stanowiska księgoznawczego"23 i wyznaczyła najważniejsze zagadnienia historyczne problematyki związków książki, bibliotek i czytelnictwa. Zwracała uwagę, że bibliotekarstwo publiczne jest najważniejszym elementem jednego z pól badawczych nauki o książce - pośrednictwa. Istotnie, lektura tego referatu nawet po latach tak wielu od jego wygłoszenia wywołuje podziw i dla erudycji młodej przecież jeszcze (33-letniej) autorki, w dodatku zajmującej się przede wszystkim czy niemal wyłącznie dawną książką i dla Jej umiejętności tak

22 Nieznany bibliofil polski XVI wieku Maciej Bech. O potrzebie badań proweniencyjnych, „Roczniki Biblioteczne”, 21:1977, z. 1-2 (druk: 1978), (poz. 156).

${ }^{23}$ K. Migoń, Z dziejów nauki o książce, Wrocław 1979, s. 88. 
jasnego, niesłychanie zwięzłego, a przecież precyzyjnego zarysowania linii rozwojowych bibliotekarstwa publicznego w Polsce. Dla Gryczowej, pełniącej przez lata obowiązki niestrudzonego, niezłomnego kustosza zbiorów bibliotecznych, naczelną funkcją biblioteki jest udostępnianie. Zwracała też w tym krótkim tekście uwagę na funkcję, jaką biblioteki mogły odgrywać w różnych okresach naszych dziejów.

Chcę zwrócić uwagę jeszcze na jedną niewielką publikację przyszłej Pani Profesor, też z 1936 r. W artykule opublikowanym w „Zaraniu Śląskim" pt. Wrażenia $z$ bibliotek cieszyńskich (towarzyszył mu i tam i w odbitce Inwentarz inkunabutów przechowywanych w bibliotekach cieszyńskich) na dziewięciu stronach przedstawiła trzy tamtejsze biblioteki, które poznała z autopsji, ale i z lektur. Świadectwem tych lektur są Jej notatki włożone do egzemplarza osobnego odbicia tej pracy przekazanego w Jej spuściźnie testamentem Bibliotece Narodowej. Notabene egzemplarz ten chyba przeznaczony był dla Piekarskiego - jest w nim odręczna notatka: „Magistro suo auctor(a) 27. VI. 1936”24. Jest też, tak jak na innych przekazanych Bibliotece Narodowej książkach piękny Jej ekslibris. W artykule pisała o dziejach i dniu dzisiejszym trzech bibliotek, zwracała uwagę na szczególnie cenne lub interesujące okazy. Nie skupiała się jednak tylko na poszczególnych drukach, ani nawet historii danego zbioru, ale uogólniała swe obserwacje. Formułowała też, jak wiele razy później, postulaty. Proponowała komasację wszystkich zbiorów bibliotecznych Cieszyna przy Muzeum Książki, by łatwiej zapewnić im odpowiednie warunki i opiekę. W interesie nauki polskiej postulowała przede wszystkim rejestrację starych druków.

Podobnych przykładów niewielkich prac autorstwa Gryczowej raczej rzadko przywoływanych w piśmiennictwie bibliologicznym i w opracowaniach poświęconych samej Pani Profesor można przywołać wiele. A przecież także w nich, a nie tylko w obszernych monografiach i bibliografiach, cieszących się zasłużonym uznaniem księgoznawców i historyków nie tylko książki, wniosła tak wiele w naszą wiedzę o książce, uczyła też prawidłowych, nowoczesnych metod badawczych i jasnego, ścisłego w zakresie używanej terminologii języka. Niemniej istotne a może nawet donoślejsze niż te drobiazgi i „fragmenta” a nawet i wielkie dzieła własne, są podjęte z Jej inicjatywy i kierowane przez Nią prace zespoło-

${ }^{24}$ Egzemplarz ten, przechowywany w bibliotece podręcznej Zakładu Starych Druków, ma sygnaturę BN 992.906. W Bibliografii opracowanej przez Wolińską opisane jako osobne pozycje (nr 17 i 18) teksty zamieszczone w „Zaraniu Śląskim”, podano też informację o istnieniu wydanej w Cieszynie odbitki. 
we, w znacznej mierze realizujące idee Kazimierza Piekarskiego. W tych pracach zespołowych autorsko uczestniczyła bardzo wydatnie, by przywołać choćby Incunabula Poloniae i tomy Drukarzy dawnej Polski. Tak więc, choć - jak napisałam na wstępie - sama nie sformułowała własnego modelu badań księgoznawczych, nie poświęciła temu żadnej osobnej rozprawy czy artykułu, choć pisała o tym przy różnych okazjach, na marginesie przedstawiania różnych problemów, to ma Ona wybitne miejsce wśród badaczy polskiej książki, a Jej wkład w dorobek polskiej nauki o książce jest rzeczywiście duży.

\section{Summary}

\section{The Contribution of Professor Alodia Kawecka-Gryczowa to the Progress of Bibliology}

Alodia Kawecka-Gryczowa never actually expressed in writing her understanding of the model of bibliological research. Nevertheless, trained by two outstanding scholars: a historian of culture Stanisław Kot and a booklore specialist Kazimierz Piekarski, she consequently perfected their methods, and at times modified their methodology, as well as the theoretical foundations of her research-domain. The author of the article attempts to demonstrate this on the instances of numerous articles, studies and catalogues prepared and published by Alodia Kawecka-Gryczowa herself, or under her guidance. Special attention is paid to incunabula studies and the research on $16^{\text {th }}$ century books, while specific situations are recalled to show certain aspects of Professor Kawecka-Gryczowa's personal characteristic traits. 


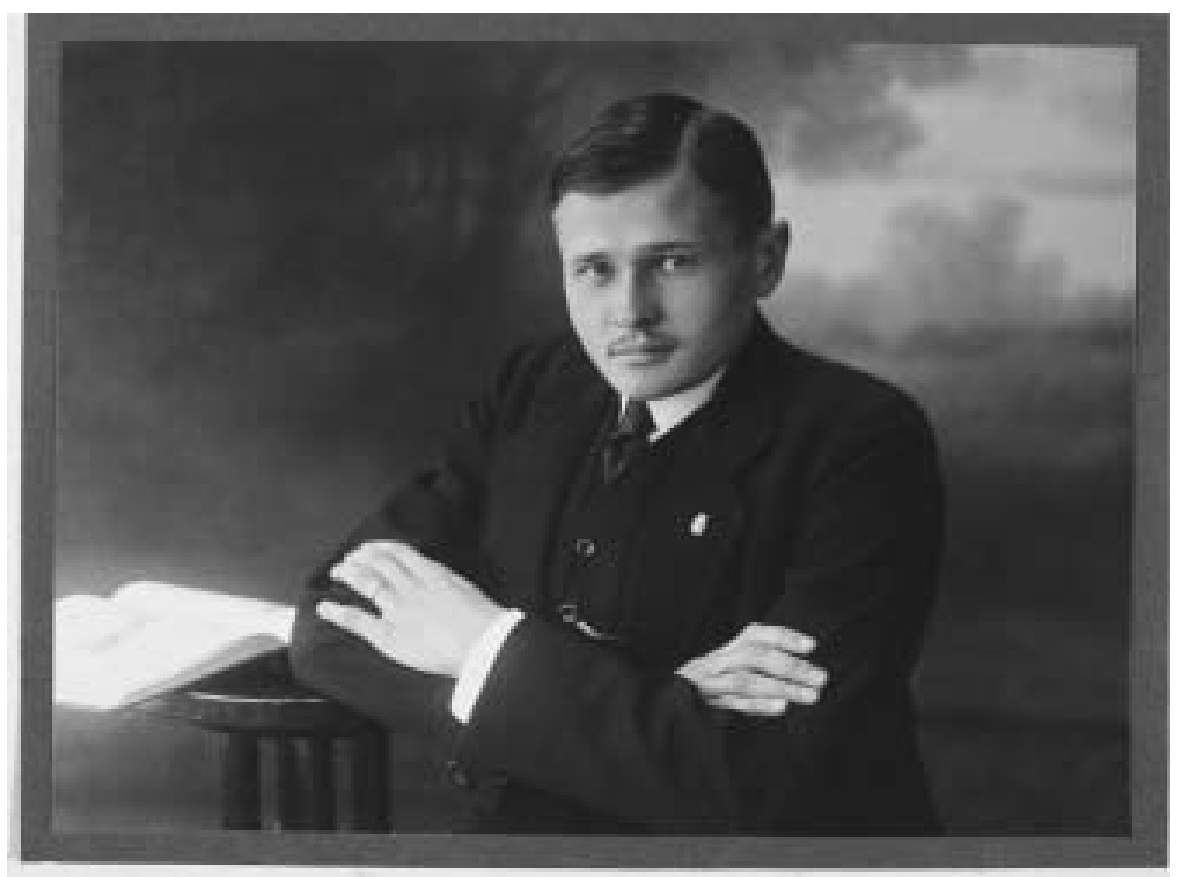

Józef Grycz, 1913 r.

(zdjęcie ze zbiorów Zakładu Rękopisów BN) 